\title{
Analysing Teaching Strategies Teachers use to Develop Communicative Competence in Secondary School English Language Learners.
}

\author{
Wise Mwelwa*, David Sani Mwanza \\ The University of Zambia
}

*Corresponding Author: Wise Mwelwa, The University of Zambia

\begin{abstract}
English has always been the language of government business, judiciary, media and employment and a compulsory subject from grade five to the final year of secondary education while Zambian languages are used as medium of instruction from grade 1- 4 and as a subject from grade 5-12 and have largely performed the role of preserving Zambian culture and heritage as noted by (Wakumelo 2013). This implies that the teaching of English in schools is of paramount importance. In line with this, the Zambian Senior Secondary School English Language Syllabus recommends two general methodologies, the communicative language teaching approach and Text Based Integrated Approaches. This clearly, entails that communicative competence is the aim of teaching English in Zambian secondary schools, as it is critical for mobility in education and is seen as a symbol of people's aspirations for quality in education and a fuller participation in national and international life. However, we did not know what classroom teaching strategies teachers were using to teach English grammar aimed at developing learners' communicative competence. The objective was; to analyze teachers' classroom teaching strategies aimed at developing communicative competence in learners used during English grammar lessons. The study was qualitative and data were collected through interview guides and classroom observation guides. The sample size was 4 secondary schools, 20 teachers of English and 4 heads of departments. The collected data were analyzed thematically. The findings revealed a number of strategies teachers were employing in teaching English grammar lessons aimed at developing communicative competence in learners which included; group discussions, sentence construction and oral presentations, teacher simulations, brain storming and context based storytelling. However, in 7 out of the 8 lessons observed, teachers were not contextualizing these strategies so as to bring real life application of the grammar learners were learning. In view of these findings; universities and colleges of education should come up with professional development programs aimed at keeping in-service teachers abreast with the recommended methods through short intensive courses during school holiday, schools to intensify on continuations professional development programs.
\end{abstract}

Keywords: Text based integrated approach, Syllabus, Communicative competence, English.

\section{BACKGROUND TO THE STUDY}

Zambia was a British colony from 1924 up to 1964and it was the British imperial and industrial power that sent English around the globe between the $17^{\text {th }}$ and $20^{\text {th }}$ century. Therefore, the legacy of the British imperialism has left many countries including Zambia with English language thoroughly institutionalized in their courts, parliaments, civil service, schools and higher education. Wakumelo (2013) noted that even after independence, Zambian leaders adopted English as an official language because they felt that the country had too many indigenous languages none of which could be accepted nationwide. English language therefore, was seen as a neutral non-indigenous language that would be accepted by all the divergent linguistic and ethnic groups in the country and thus would foster national unity.

Since then, English has been the language of government business, judiciary, media and employment, (Kashoki, 1990). "This has resulted into most Zambians being eager to learn English language due to its economic value and prospects that come with the acquisition of English language proficiency," (Mwanza 2016:39).More so,English language in Zambia is seen as a symbol of people's aspirations for quality in education and a fuller participation in national and international life, (Wakumelo, 2013). 
In line with the above developments, the Zambian Curriculum Development Center embarked on an ambitious revision of the senior secondary school English syllabus from 2011 to 2013; and the final revised senior secondary school English language syllabus was published in 2013.

The general objectives of the syllabus included the following;

"after learners have under gone through secondary school education, they should, be able to communicate effectively and appropriately in English language in various social contexts, be able to understand and speak English language well enough to function effectively (later), in tertiary education and in the world of work and recognize and apply the difference between spoken and written English," (CDC, 2013: 28).

Furthermore, the syllabus also sets out expected competences after learners have undergone through this syllabus, as outlined in this statement:

"Senior Secondary School leavers must be able to; Listen and speak in English language appropriately and effectively in various social contexts and apply listening and speaking skills in a variety of situations, well enough to function effectively, (CDC, 2013: 28)."

This too, clearly shows that, the aim of teaching English language in Zambia as clearly spelt out in the Senior Secondary School English language Syllabus is to develop proficiency or communicative competences in learners, both in written and spoken forms of English language in different domains of language use.

Therefore, the Zambian senior secondary school English language syllabus, recommends two general methodologies which should be used concurrently - the Communicative Teaching Approach and the Text-based, Integrated Approach," (CDC 2013: V). This methodological recommendation too, clearly shows that the Zambian Educational system through its Senior Secondary School English Language Syllabus is cognizant of the fact that the aim of teaching English language is to develop communicative competence in the learners.

This concept of communicative competence was originally developed in the early 1970s by a sociolinguist Dell Hymes. It was then further developed in the early 1980s by Canale and Swain. According to Canale (1983), communicative competence refers to "the underlying systems of knowledge and skill required for communication". Canale and Swain (1980:4) also define communicative competence in terms of four components: grammatical, sociolinguistics, discourse and strategic competences.

To begin with, Canale and Swain (1980) acknowledged that grammatical or linguistic competence is an essential part of being communicatively competent. This type of competence includes the linguistic forms which are traditionally subsumed under the category of grammar; including rules of sentence structure, word formation and pronunciation. In short, it looks at words and rules.

The second dimension is sociolinguistic or pragmatic competence which refers to an "understanding of the social context in which communication takes place, including role relationship, the shared information of the participants, and the communicative purpose for their interaction" (Richards and Rodgers, 1986:71).

Discourse competence is understood in terms of the interaction of individual message elements in terms of their interconnectedness and of how meaning is represented in relationship to the entire discourse or text.

Lastly, they proposed strategic competence which basically refers to the coping strategies that are employed by communicators to initiate, maintain, repair, and terminate or redirect communication (Richards and Rodgers, 2001). This therefore, led to the development of the Communicative Language Teaching Approach (CLT).

Larsen-Freeman (2000) observed that around 1970's and 80's, it became clear that communication required that learners perform certain functions such as promising, inviting, and declining invitations within a social context. In other words, the ability to communicate required more than linguistic competence; it required communicative competence, which (Hymes1971) explains as knowing when, how to say and what to whom. Hence forth, "language teaching is based on a view of language as 
communication, that is, language is seen as a social tool which speakers use to make meaning; speakers communicate about something to someone for some purpose either orally or in writing," (Berns, 1990).Widdowson (1990) therefore, asserts that it is such observations which contributed to the shift in the field of language teaching from linguistic structure-centered approaches to communicative approach. Communicative language teaching (CLT) therefore, takes all the four dimensions of communicative competence by looking at language as a whole in its approach to second language teaching.

Hence forth, Many studies have been done in the area of English language teaching in Zambia by other scholars like; Mumba (2019) who looked at the implementation of Text Based Integrated Approaching in the teaching of English in Luanshya District, Nyimbili (2017) also looked at the use of learner centered techniques in the teaching of English language in selected secondary schools of Lundazi District, Chishipula (2016) looked at the implementation of CLT in selected primary schools of Lusaka District, Zulu (2016) looked at challenges teachers face in the implementation of CLT in selected schools, then Mwanza (2016) looked at the use of the ecclectic method in the light of English grammar teaching, Sakala (2012) also conducted a study were he sought to establish the factors which contributed to the excess use of the lecture method and Munakaampe (2005) who looked at why teachers were not implementing CLT in selected Lusaka schools. In all these studies, there was a look at CLT as a method used to teach English in general and not on the goal of CLT which is to develop communicative competence in learners as emphasized in the approach itself (CLT) and in the 2013 revised Zambian senior secondary school English language syllabus.

\section{Statement of The Problem}

In line with the above statements, the Zambian Senior Secondary School English Language Syllabus recommends two general methodologies, the communicative language teaching approach (CLT) and Text Based- Integrated Approach (TBIA), (CDC, 2013: VII). This clearly, entails that communicative competence is the aim of teaching English in Zambian secondary schools as it is critical for mobility in education and is seen as a symbol of people's aspirations for quality in education and a fuller participation in national and international life. This therefore, calls for teachers who are the implementers of the syllabus to understand and ensure that they foster the development of communicative competence in the learners in their teaching. The syllabus further states that "the teachers' task is to provide effective learning experiences/activities which will enable the learners achieve the planned communicative goals," (CDC, 2013: VII). However, it was not known as to what classroom strategies teachers of English employed and how they employed those strategies when teaching English language (grammar) to grade eleven (11) learners in order to develop communicative competence in learners. Therefore, as a question, the research problem was: whatclassroom strategies did teachers of English language use to teach English grammar lessons aimed at developing communicative competence in learners in selected Secondary Schools of Nakonde District?

\section{Purpose OF THE STUdy}

The purpose of the study was to establish teachers' classroom teaching strategies aimed at developing communicative competence in learners used during English grammar lessons in selected Secondary Schools of Nakonde District.

\section{Methods AND Materials}

This study was qualitative and it targeted all secondary schools, all teachers of English language and heads of department for literature and languages' departments, in Nakonde District. The sample size was 4 secondary schools, 20 teachers of English and 4 heads of departments, and these were purposively sampled. Data were collected through interview guides and classroom observation guides. The collected data were analyzed thematically according to the objective and question of the study. The analysis of the data was also analyzed through the lenses of the code and pedagogic discourse theory whose proponent is Bernstein (1973) whose main argument is that classroom learning does not happen in a vacuum as it is affected by other factors such as teachers, pupils and the education system. Therefore, this theory was used to establish how these factors affected teachers classroom strategies used to English whose aim is to develop communicative competence in learners. 


\section{DATA Presentation}

This study sought to analyze teachers' classroom strategies aimed at developing communicative competence in learners used during English grammar lessons. To answer this question, interviews were conducted with 20 grade eleven teachers of English and four heads of department (HODs) for literature and languages department. To further solicit answers to this question, eight (8) classroom lesson observations and post lesson observation interviews were done. These interviews and lesson observations were also video and audio recorded and transcribed for easy interpretation and analysis.

\subsection{Strategies Teachers used to teach Communicative Competence: Lesson Observations Data.}

This section presents the findings on how selected teachers of English in the four selected secondary schools taught communicative competence through their classroom teaching strategies. In order to elicit this set of data, the researchers observed eight English grammar lessons, which were videorecorded for easy interpretation and analysis. For purposes of this paper, only four lesson descriptions will be presented and analyzed. The first part of the data will comprise lesson descriptions and this will be followed by interview data. The reason for conducting both interviews and lesson observations was because respondents have a tendency of saying what they don't do and doing what they don't say (See Mwanza, 2016). In terms of coding of data, the four secondary schools used in this study are referred to as schools A, B, C and D and the corresponding teachers as Teachers A, B, C and D respectively.

\subsubsection{School A/ Lesson A/ Teacher A}

The school is located within the urban area. The teacher is female and holds a Bachelors Degree in Education from a public university college. The class has 67 learners. The teacher has a well prepared lesson plan.

The teacher writes the topic on the board "conditional sentences type two improbable". Thereafter, she asks learners what improbable conditional sentences are and asks for examples of its use. One pupil responds by stating his answer and gives the following example; if Janet came home, I would give her the money. After two more correct examples, the teacher thanks those learners who attempted to answer and those who gave correct answers and encourage them to keep up it.

Thereafter, she mentions that today's lesson is a continuation of conditional sentences we started last time so today's lesson is on "impossible sentences". She asks the class to read the topic and they do so repeatedly. Then, she asks the learners what the term impossible meant. A girl gives a correct answer and the teacher remarks "very good". She asks for examples, when a correct answer is finally given, the teacher remarks "correct". Then the teacher gives a brief explanation of the day's structure by stating that if + past perfect tense + perfect condition is the compositional structure of these sentences. Thereafter, she asks for groups to discuss and give more examples, as answers are being given, the teacher emphases on important points to the whole class.

Thereafter, the teacher asks learners to construct sentences using the conditional sentence discussed. After several oral sentence presentations by some learners, she asks if there are any questions. 'No questions' the learners chorus together. Then the teacher asks the learners to get the exercise books and write the class exercise. The teacher writes the exercise on the board from a textbook in which she asks the learners to use 'but for'; to indicate negative conditions individually. She does so by first writing an example. Then, she asks the learners to read through the examples loudly together. The class does that twice. Afterwards, she continues to write the question on the board which learners had to answer and the lesson ends with the teachers getting learners books for marking.

\subsubsection{School B/Lesson B/Teacher B}

This male teacher has a Master Degree in African languages. The school is situated in a peri urban area. There are 61 learners in class. The teacher has a lesson plan.

The teacher brain storms the learners as a whole class with the following sentence; 'James lost the book which her father had given her'. Thereafter, he asks the learners to identify the type of structure being used in the sentence. The learners became quiet. Therefore, the teacher explains to the learners by mixing both their local language and English language; the sentence given has used 'which' to join 
the two sentences by defining the book which James lost and this structure is called a relative pronoun' and the clause is now called 'relative clause' because it has defined the noun that came before other nouns and distinguishes the noun from others of the same type. Then the teacher asks the learners to turn to page 86 of the text books. He refers the learners to sentences where the discussed structure has been used and asks the learners in their groups to join given sentences using 'who', 'that,' 'which,' 'whom' and 'whose'. Thereafter, the teacher asks learners to do oral presentations of the group answers while he consolidates when he feels there is need to do so.

In concluding the lesson, the teacher gives the learners a dialogue in a text book based on the taught concept and asks them to finish in pairs and present the whole dialogue to the whole class. Thereafter; he recaps on key points using oral question and answers.

\subsubsection{School C/Lesson $\mathrm{C} / \mathrm{Teacher} \mathrm{C}$}

The teacher is male and holds a Secondary school teachers' Diploma with a major in English Language Teaching. The school is located within the urban area. The class has 58 learners. The teacher has no lesson plan.

The teacher explains that basically there are three cardinal tenses. Then he asks the class to state these tenses. Thereafter, he explains to the class, 'the focus today is on the present simple tense' and went further to state that this tense can be divided into four categories. Then he asks the learners what are these categories? And then the learners mentioned the four correctly. The teacher then gives learners in pairs to discuss and state how each of these types is formed in verbs ending with; 'o', 'ch', 'sh', or 'ss', and ' $y$ '. Then he allows the pairs to make oral presentations and explain the rules governing the changes effected on each of the verbs ending with the above given letters. The teacher clarifies that verbs ending with the above stated sounds, when used with the third person singular (he/she/it) you have to add 'es', for example 'go' changes to (he/she/it goes), 'catch' changes to (she/he/it catches) and 'push' changes to (it/he/she pushes) respectively.

Then the teacher tells the learners to state the uses of the present simple tense and give at least two examples of each of the uses in pairs. Learners protest, teacher then explains the four uses of the stated tenses and gives an example on each of the four uses and then some learners shout "this is ok now!" to show that they have now gotten the concept then he asks if it is clear. The whole class chorus together "yes". After that the teacher makes the whole class to stand and then asks each pupil to construct a sentence using the present simple tense and present it to the class. If a pupil gives a correct answer he/she sits down. After a few correct sentences are presented by the learners, the teacher tells the whole class to sit and get their exercise books and write a class exercise individually. Thereafter, the teacher summarizes the key points of his lesson and asks the learners to fill in the gaps with appropriate verb forms based on the taught concept.

\subsubsection{School D/ Lesson D/ Teacher D}

This teacher is female and has a Bachelor's Degree in English Language Teaching. The school is a day school and it is situated in a peri urban area. She has a lesson plan. There are 49 learners in class.

The teacher presents a story to the class and at the end asks for reactions from the learners using the structure taught the previous day and some pupils were able to make sentences using the concept correctly though some learners had challenges coming up with those sentences. Then the teachers introduces the day's work on 'prepositions' and asks the learners to define the term preposition. Learners give answers; for instance learners 1 said: "it's a word that shows a relation of a given word to other words" while another learners said: "it's a word that shows us how words are related in a sentence". Teacher says all answers are ok, she then emphasizes on the correct meaning of the word and she adds, "A preposition shows the relationship of a noun/pronoun to another word in a sentence." She then states that prepositions can be divided into three categories for easy understanding and writes prepositions of; movement, expression and position, on each of these the teacher gives examples.

Thereafter, she asks three learners go in front and then she tells them to sit on a desk. The teacher then gives the following sentence to the class; 'Ted is sitting to Timothy' and then teacher asks the whole 
class what is wrong with the sentence. Some learners point out that a preposition is missing then the teacher asks why? Then one learner says:"because it is not telling us how Ted is sitting with timothy", therefore, the learner said:"the preposition 'next' has to be put between 'sitting' and 'to', to make the sentence meaningful." After that, the teacher recommends the learner for the correct answer and good explanation.

Thereafter, the teacher asks the learners to construct sentences using any of the prepositions discussed in the lesson which included; next, under, on, between, besides and behind to mention but a few, after that, she asks the learners to present their sentences to the class. Some sentences made by some learners though correct, were full of humor therefore they made the teacher laugh and while laughing the teacher, encouraged the learners that they were entitled to make their own sentences using their own opinions and after more sentences were given, the teacher summarized the responses and thanked all the learners for participating actively in the lesson. The class teacher ends the lesson by giving homework and thanking the learners for their cooperation.

In conclusion on this section, the figure below gives a summary of teachers' classroom strategies aimed at developing communicative competence in learners, noted during English grammar lessons from lesson observations conducted in the four selected secondary schools in Nakonde District.

Table1. A summary of teachers' classroom Strategies, teachers used during English grammar lessons, aimed at developing communicative competence in learners.

\begin{tabular}{|l|l|}
\hline School code & Teachers' classroom teaching strategies used during English grammar lessons \\
\hline School A & $\begin{array}{l}\text { Whole class discussions, presentations, group work, repetitive drills, chorusing, oral } \\
\text { question and answer and teacher exposition }\end{array}$ \\
\hline School B & Group work, pair work, individual sentence construction and presentation \\
\hline School C & $\begin{array}{l}\text { Oral question and answers, teacher exposition, pair work, individual sentence construction, } \\
\text { oral class presentations. }\end{array}$ \\
\hline School D & $\begin{array}{l}\text { Oral question and answer, class discussion, brain storming, individual sentence } \\
\text { construction and oral presentations }\end{array}$ \\
\hline
\end{tabular}

\subsection{Strategies used by Teachers to Teach Communicative Competence: Interview Data}

To get more insights into the study, the researcher also conducted oral interviews with the heads of department and the teachers. The researcher asked the heads of department and the teachers to state the two general recommended approaches for teaching English in the Zambian senior secondary schools which were in line with the aim of English teaching as stated in the syllabus.

With regards to the answers to the above question, some teachers were able to state one correct recommended approach pairing it with a different approach which is not recommended. Take for instance this response from teacher 3 who said:

Cognitive and communicative approaches are recommended in the syllabus (T3).

The other teacher for instance, just gave one correct approach and said: text based integrated approach and did not give the other one. Similarly teacher 11 also said:

Communicative teaching approach and structural teaching approach (T11).

While on the other hand, other teachers showed that they were not even sure if there existed something like recommended approaches in the teaching of English in Zambian schools as they expressed mixed reaction when asked to state the recommended approaches. For instance one of the male respondents said:

Approaches differ according to the component being taught but did not state any of those different approaches he referred to (T4).

In addition to that another teacher also said:

I am not aware of the two general recommended approaches stated in the syllabus that I am required to use to teach English but I teach based on the approaches I know (T6).

Another teacher told the researcher that;

Approaches are many and we just pick on those we feel will help us to deliver a particular lesson. Learners are also engaged in their own learning through group works, class discussions, for instance by asking learners to go in front and then ask them to present their answer orally (T2). 
While others out rightly told the researcher that they did not know anything, for instance teacher 20 just said:

\section{I have no idea (T20).}

Other teachers struggled to give answers and when they later managed they gave different approaches which were not even closer to the recommended approaches. For instance teacher 1 said:

\section{Audio lingual and learners centered (T1).}

In the same line teacher 17 also said:

\section{Grammar translation and structural approaches (T17).}

On a contrary, while the above responses were common amongst the teachers interviewed, one teacher was able to give the correct answer and the teacher said:

Communicative approach and text based integrated approach are the general recommended approaches for English teaching in Zambia (T9).

Apart from the twenty teachers, the heads of department (HODs) were also asked to state the general recommended approaches for teaching English in the Zambian senior secondary schools as stated in the syllabus which were in line with the aim of English teaching in schools, which was to develop communicative competence in learners. The responses varied from one respondent to another and just like the teachers, some were at least able to mention one correct recommended teaching approach pairing it with a wrong one. For instance the following response from HOD 1 who said:

\section{Communicative approach and audio lingual approach}

Similarly, HOD 3 said:

\section{Text based integrated approach and structural approach}

While the other respondent completely failed to state any of the recommended approaches but just mentioned other approaches that were not recommended, for instance HOD 2 said:

Learner centered and subjective teaching approaches.

The other respondent also said approaches differ in use depending on the topic being taught in a particular lesson. For instance this head of department said:

The issue of which approach is recommended or not, mostly do not work because we just teach basing on the topic being taught, our abilities as teaches and the abilities of our learners (HOD 4).

\section{Data Analysis}

The study established a number of teachers' classroom teaching strategies aimed at developing communicative competence in learners that teachers in this study used during English grammar lessons. Findings revealed that teachers frequently used the following classroom teaching strategies; whole class discussions, group works and discussions, sentence construction and presentations, simulations, teacher expositions; brain storming oral questions and answers. These strategies revealed in this study are similar to what Luangala, (2010) in his study on teaching strategies under learnercentered learning which revealed. He stated group work, pair work, role play, debate, presentations, group discussion, question and answer and individual work as activities teachers were employing in learners centered teaching and learning in schools. Similarly, these strategies revealed in this study are also in line with what Nyimbili(2017) stated in his study on the use of learners centered techniques that; pair work, group work, role play, problem solving, question and answer, debate and brain storming were some of the activities teachers were using to teach English under the learner centered approach. He also went further to state that teachers used these activities according to the subject, grade and cultural background of their learners and he also said that commitment on the teacher's side also mattered in the usage of these activities in the teaching of English in schools. Similar findings were also echoed by Mtika (2014) who also did a similar study in Malawi and his findings revealed that teachers were unable to use all the learner centered techniques in schools but just used some because the classes were over enrolled.

In terms of teaching materials to develop communicative competence, Richard (2001) stated that one of the instructional practices promoted by communicative language teaching (CLT) is the extensive integration of authentic materials in the curriculum. Authentic materials refers to the use in teaching 
of texts, photographs, video selections, and other teaching resources that were not specially prepared for pedagogical purposes (Richards 2001). Examples of authentic audiovisual materials are announcements, conversations and discussions taken as extracts or as a whole from radio and television public broadcasting, real-life telephone conversations, messages left on answering machines, or voice mail. There are numerous justifications for the use of authentic materials. They contain authentic language and reflect real-world language use (Richards 2001). In other words, they expose students to real language in the kinds of contexts where it naturally occurs. The use of authentic materials also supports a more creative approach to teaching; that is, its use allows teachers to develop their full potential, designing activities and tasks that better match their teaching styles and the learning styles of their students. However, the use of authentic materials and contextual situations were absent in all the four lessons cited in this study which was a clear indication that learners were learning language as an abstract thing and that affected their development of communicative competence.

This use of authentic materials in the curriculum espoused by Richard (2001) agrees with the analytical model and its extended notions of resemiotisation and semiotic remediation used in this study. Kress (2010) observed that traditionally, classroom research focuses on teachers and learners using spoken language to communicate in the classroom, with books as teaching materials. Multimodality recognizes that while spoken or written language is important in classroom communication between teachers and learners, there are other modes or semiotic resources which are available and can be used. They further argued that learning does not depend centrally on language (written or spoken) but on other modes too which include image, gesture, action with models and writing. Bock (2014) adds that multimodality recognizes that all communication (including classroom communication) uses a variety of modes. Modes are defined as the different semiotic resources used for making meaning both verbally (speech) and non-verbally (image, gesture, gaze, posture, music, color and discarded objects).

It was further observed that in almost all the classes and lessons the researcher observed, teachers at least employed some learner centered classroom teaching strategies. In that, most teachers at least made learners actively participate in their own learning. However, these learners centered classroom teaching strategies that teachers were employing did not reflect the aim of English language teaching which is to develop learners' communicative competence, because teachers were not integrating all the four dimensions of communicative competence. They were just focusing on linguistic/ grammatical competence and neglecting the other three dimensions of communicative competence, which if well integrated can bring about a holistic communicative competent English learner. Some teachers even made their learners to stand and only sit after giving a correct answer based on the taught concept. This practice encouraged learners' involvement in the lessons, although it was not good enough to foster the development of communicative competence in them, because the sentences that were constructed and presented still lacked contextual situations and real life language usage scenarios as they were not contextualized. This practice by the teachers of just targeting grammatical competence in their classroom teaching strategies at the expense of the other three dimensions of communicative competence. Contradicted what Lindsay and Night (2006) stated:

Communicative Language Teaching puts emphasis on language in use rather than language as structure. It focuses on all the four language skills of speaking, listening, writing and reading. Practice of pronunciation, stress and intonation is a vital component; language learning is based on real life situations. Hence, the students' communicative competence is the objective, rather than linguistic competence.

This practice by teachers, further contradicted the fact that they were able to define communicative competence. Therefore, they were expected to do well in terms of their pedagogical approaches to English grammar teaching by encompassing all the four dimensions of communicative competence which Canale and Swain (1980) called as:

Grammatical or linguistic competence, which they said is an essential part of being communicatively competent. This type of competence includes the linguistic forms which are traditionally subsumed under the category of grammar; including rules of sentence structure, word formation and pronunciation in short it looks at words and rules. 
Sociolinguistics or pragmatic competence which refers to an "understanding of the social context in which communication takes place, including role relationship, the shared information of the participants, and the communicative purpose for their interaction.

Discourse competence is understood in terms of the interaction of individual message elements in terms of their interconnectedness and of how meaning is represented in relationship to the entire discourse or text and;

Strategic competence which basically refers to the coping strategies that are employed by communicators to initiate, terminate, maintain, repair, and redirect communication.

But what was revealed through the transcribed lesson observation data presented in the previous section showed that teachers focused on developing grammatical/linguistic competence in learners while overlooking sociolinguistic, discourse and strategic competencies which are equally important in the conceptualization and realization of communicative competence. This was against the principle of teaching language as a whole which is the hallmark of Communicative language teaching. Besides, it is clear that although most teachers showed good understanding of communicative competence, they could not practically expose learners to all the four aspects of the concept. For instance, in almost all the four lesson observations, teachers started their lessons by explaining the rules governing the use of a given structure using teacher exposition strategy and then in most cases they involved learners in making sentences based on the taught concept, either through group work, individual work or group discussions and in one of the classes the teachers had even used a story to try and bring a context in his teaching which was a plus on his part. This shows that having knowledge of the theory does not automatically mean that one possesses practical skills implied by the theory. What we see here is that teachers were not meeting the goal of teaching English. Mwanza (2017) argued that teachers' conceptual/methodological misunderstanding accounts much for their failure in English language teaching in Zambia. This finding has practical implications for teacher preparation. Manchishi and Mwanza (2018) as well as Kombe and Mwanza (2019) argued for teacher training institutions to invest a lot of their focus on developing both theory and practical skill in teachers in order for them to respond to the needs of a school teacher.

Teachers' focus on just one component of communicative competence was not enough pedagogically to enable learners develop communicative competence, because modern language teaching and learning emphases on context based learning where real life communication scenarios are brought into the classroom situation so as to develop a holistic language user (Richard 2001). Therefore, this approach to grammar teaching by the teachers in this study also neglected the other dimensions of communicative competence and lacked the contextual application of the taught structures to enable learners appreciate the real life language use, which is also the aim of CLT and the Zambia senior secondary school English syllabus (CDC 2013). Larsen-Freeman (2000) observed and stated that around 1970's and 80's, it became clear that communication required that learners perform certain functions such as promising, inviting, and declining invitations within a social context. In other words, the ability to communicate required more than linguistic competence; it required communicative competence, which (Hymes 1971) explains as knowing when and how to say what to whom. Hence forth, from that time "language teaching is based on a view of language as communication, that is, language is seen as a social tool which speakers use to make meaning; speakers communicate about something to someone for some purpose either orally or in writing" (Berns, 1990). Therefore, teachers should realize that they can meet the aspiration of the curriculum better by adopting the principles of CLT in their classrooms, because these principles and techniques if put in practice develop learners' English communicative skills.

Yet, for instance, most teachers introduced their lessons by explaining the rules that governed the grammatical structure under discussion. Then they later gave examples on how to use that particular structure and then went forth to let learners practice using that structure through individual or group sentence constructions and presentations. But all these strategies did not contextualize the learning process. While as teachers, they facilitated the learning process by moving around the class checking what the learners were doing. That was a commendable pedagogical practice by the teachers. Just like it was also noted by Aschermann (2010:46) who said: 
Cooperative activity settings in a classroom allow children to create their own path towards a specific goal. These areas are more flexible and give children a more open area to work and interact. By providing these learning environments in a classroom, children are able to form a cohesive group task where they can express their ideas.

Further, the researcher observed that in almost all the schools he visited and lessons he observed, teacher were using similar strategies in teaching English grammar lessons aimed at developing learners' communicative competence. These teachers neglected contexts which can bring about meaningful language usage, which can also arouse interest in learners to learn the target language. Guthrie, (2011) also noted that some teachers sampled few techniques or strategies in their teaching because they hardly wanted their learners to take the center stage as creators of knowledge instead they were supposed to listen and get knowledge from the teachers. Therefore, they chose activities which needed their control at all cost. Guthrie lamented that with this cultural perception, it means that learning in secondary schools will continue to be on the same learner centered techniques. This revelation andnotion, also contradicts what Brunner (1966) noted about the teaching and learning processes. He said the teacher is a facilitator of learning while the learner constructs knowledge through activities in the classroom and experience.

It was clear from the lesson observations that teachers at times code switched to local languages so as to ensure that learners got the concept. This practice agrees with the concept of democratization of the classroom through the avoidance of symbolic violence which calls for Translanguaging as a pedagogic practice, (Mwanza 2017). Translanguaging embraces multiple languages in the classroom and views them, as resources that can enhance learning and teaching in a classroom. This agrees with the pedagogic discourse theory which holds that classroom learning is not done in a vacuum but rather in an environment where it is affected by many other factors such as language barrier (Bernstein 1973).Therefore, one of the advantages of Translanguaging is that "it enables certain concepts to be reinforced through repetition in several languages and clarified in much more detail as opposed to using one language" (Hassan and Ahmed 2015: 26). Other benefits of Translanguaging as postulated by Baker (2011) are the promotion of deeper and fuller understanding of the subject matter; helping in the development of the weaker language; and the linking of home and school, thereby facilitating the cognitive powers of the learners.

The study also revealed that teachers were at times asking learners to work alone, construct sentences and make notes in groups or pairs before a class presentation. Teachers went round the groups, pairs or visited desks where learners were discussing the given tasks and facilitated the learning processes. This revelation by this study on how some teachers tried to make sure that learners were at the center of their own learning through their classroom teaching strategies, agrees with what Brunner (1966) who stated that a teacher is a facilitator of learning while the learner constructs knowledge through activities in the classroom and experience. In this case, a learner was treated as a participant in the teaching-learning process and not as a passive listener. The finding also agrees with Munsaka (2011) who said;

Teachers need to ensure that learners remain at the centre of the teaching-learning process. Learners should be viewed as active participants in the teaching and learning process and not as passive receivers of information. Therefore, a teacher should not dominate the classroom but use learner - centered approaches were his/her instructions in class take into account the learners as partners in classroom activities.

In conclusion, proponents of Communicative approaches and specifically those who defend CLT postulate that the main aim of this language teaching process is for learners to acquire the language rather than to learn it by mastering grammar rules. Therefore, they argue that there should be a shift in the way classroom instructions are done, from being teacher centered to being learners centered (Richards 2006: 9).

\section{IMPLICATION ON PEDAGOGY AND RESEARCH}

However, the successful implementation of the two above stated recommended approaches; require that teachers are adequately trained to teach English. Teacher training has been implicated inmany studies (Chishipula 2016, Mulenga 2015, and Manchishi and Mwanza 2018) noted inadequate teacher training as affecting the successful implementation of the recommended methods and approaches of 
teaching in schools. This implies that universities and colleges of education training teachers should offer adequate training to trainee teachers of English language in syllabus interpretation, the Communicative Teaching Approach and the Text Based Integrated Approach by ensuring that they are equipped both with the theoretical and practical knowledge upon graduation (Chileshe, Mkandawire and Tambulukani, 2018). This means that during teacher training, student teachers should be trained adequately in approaches, methods and strategies in line with the curriculum and its aim.

Further, there is need for continuing professional development activities among practicing teachers in order to acquaint them with skills and knowledge on the trends in methods. This is so because teachers' misconception about a method or approach can lead to either non application of the method or approach and at most, wrong implementation of the method, (Mwanza, 2017). Therefore, the ministry of general education in partnership with colleges of education of education and universities to deliberately come up with short intensive continuous professional development programs through short courses during school holidays. Lastly, the university of Zambia being the highest institution of learning training teachers and overriding all other such institutions in the country, should provide capacity building to colleges of education in English pedagogy.

\section{CONCLUSION}

The main purpose of the study was to analyze teachers' classroom strategies aimed at developing learners' communicative competence during English grammar lessons in selected secondary schools of Nakonde District. Therefore, to get the data oral interviews and classroom lesson observations were conducted and the findings presented above have revealed a number of classroom strategies which teachers were using to teach English grammar lessons aimed at developing Communicative competence in learners in the four selected secondary schools and these included; whole class discussions, group work, individual sentence construction and oral presentations, teacher expositions, brain storming oral questions and answers, storytelling and conversations. These classroom strategies were based on the tenets of CLT, one of the two general recommended teaching approaches for English language teaching in Zambian Secondary Schools.

\section{REFERENCES}

[1] Berns, M. S (1990). Contexts of competence: social and cultural considerations in communicative language teaching. New York: Planum.

[2] Bruner, J. S. (1987). The theory of A. R. Luria: Functions of spoken language in the development of higher mental processes. London: Lawrence Erlbaum.

[3] Canale, M and Swain, M (1980). Theoretical Bases of communicative approach to second language teaching and testing, Applied linguistics, 1, (1), 1- 47. http://dx. doi. Org/10.1093/applin/1/.

[4] CDC (2013). Revised Senior Secondary School English language syllabus. Lusaka: Government printers.

[5] Chishipula, J (2016). Factors hindering teachers fro of English language from implementing communicative language teaching (CLT) approach, unpublished Masters Dissertation, Lusaka: university of Zambia.

[6] Halliday, M. A. K (1978). Language as a social semiotic; London: Edward Arnold.

[7] Haugen, C.R. (2009).Recontextualisation of Trainability: Learning Strategies and Social Background. In Contextualization and Recontextualisation of Discourses on Equity in Education (pp. 143-167). PhD Thesis, Trandheim: Norwegian University of Science and echnology.

[8] Howatt, A. P. R (1984). A study of English language teaching. Oxford: Oxford university press.

[9] Hughes, M and Vass, A (2001). Strategies for closing the learning gap; New York: Educational press. ISBN: 185539072.

[10] Hymes, D (1972). 'On communicative competence' in J.B pride and J. Holmes (Ed) sociolinguistics: selected readings harmond worth: Penguin, pp 269- 99. IN: Phi Delta Kappa. International Journal of Educational Development, 30: 396-404.

[11] Kashoki, M. E (1990). The factor of language in Zambia; Lusaka: Kenneth Kaunda Foundation.

[12] Kombe, C., \& Mwanza, D. S. (2019). The 2014 Zambian Revised Literacy Policy in Primary Schools: Were Teachers Prepared to Implement It? International Journal of Humanities Social Sciences and Education (IJHSSE), 6(8), 115-131. 
[13] Kress, G. (2010).Multimodality: a Social Semiotic approach to contemporary communication. London. New York: Rout ledge

[14] Larserand Freeman (2011). Techniques and Principles in Language Teaching. (With Anderson, M) ( $3^{\text {rd }}$ Ed), Oxford: Oxford University Press.

[15] Luangala, J. R. and Mulenga, I. M. (2010).Cultivation of thinking skills through instructional procedures: The case of selected Basic Schools in three urban districts of Zambia, a research study report. Lusaka: University of Zambia.

[16] Manchishi, P.C., \& Mwanza, D.S (2018). Reforming School Experience in Pre-Service Teacher Preparation for Quality Teacher Graduates. Multidisciplinary Journal of Language and Social Sciences Education, 1(2), 1-26.

[17] Ministry of Education, (2013). Education Curriculum Framework 2013. Lusaka: Curriculum

[18] Mohlabi-Tlaka, H.N. (2016). The contribution of a Text-based approach to English Education for communicative competence,' PhD Thesis, University of Pretoria, Pretoria

[19] Mtika, P. and Gates, P. (2014). "Developing Learner-Centered Education among Secondary Trainee Teachers in Malawi: The Dilemma of Appropriation and Application." International Journal of Educational Development, 30: 396-404.

[20] Mumba, C (2019). Teachers' Implementation of the Text Based Integrated Approach (TBIA) to grade 11 pupils in teaching English in selected secondary schools in Luanshya. Unpublished masters dissertation, Lusaka, university of Zambia.

[21] Munakampe, Y. H. (2005).A critical Appraisal of the Communicative Approach in Selected Lusaka Basic Schools: Unpublished Masters Dissertation, The University of Zambia.

[22] Munsaka, E (2011).Mastering the Psychology of Teaching and Learning. Ndola: Mission Press

[23] Mwanza, D.S (2016). A critical Reflection on eclecticism in the teaching of English grammar, Unpublished PhD Thesis, University of Western cape, South Africa.

[24] Mwanza, D.S. (2017). Teachers' Understanding and Attitudes towards the Eclectic Method to Language Teaching in Zambia. Journal of Educational and Management Studies. 7 (1), 01-16.

[25] Mwanza, D.S (2017). The Eclectic Method to language teaching: Clarifications and Conceptual Extensions. Journal of Lexicography and Terminology. 1 (2), 1-24.

[26] Richard, J. C and Rodgers, T (2001). Approaches and methods in language teaching (2 ${ }^{\text {nd }}$ Ed $)$ New York: Cambridge university press.

[27] Tingting, Q. (2011). A Comparison Between the Text-based Approach and the Dictionary - based Approach of Vocabulary Learning in a Chinese University. Kristianstad: Kristianstad University.

[28] Wakumelo, M.N. (2013). A Critical Analysis of Zambia's Language-in Education Policy: Challenges and Lessons Learned. In H. McIlwraith (Ed), Multilingual Education in Africa: Lessons from the Juba Language in Education Conference, British Council.

[29] Weideman, A. (2001). The Old and the New: Reconsidering Eclecticism in Language Teaching. Linguam, 17(1):1-13. doi.org/10.5785/17-1-131.

[30] Widdowson, H. G. (1978). Teaching Language as Communication. Oxford: Oxford University Press.

Citation: Wise Mwelwa, David Sani Mwanza. "Analysing Teaching Strategies Teachers use to Develop Communicative Competence in Secondary School English Language Learners." International Journal of Humanities Social Sciences and Education (IJHSSE), vol 7, no. 3, 2020, pp. 43-54. doi: http://dx.doi.org/10.20431/2349-0381.0703006.

Copyright: (c) 2020 Authors. This is an open-access article distributed under the terms of the Creative Commons Attribution License, which permits unrestricted use, distribution, and reproduction in any medium, provided the original author and source are credited. 